Historic, Archive Document

Do not assume content reflects current scientific knowledge, policies, or practices. 



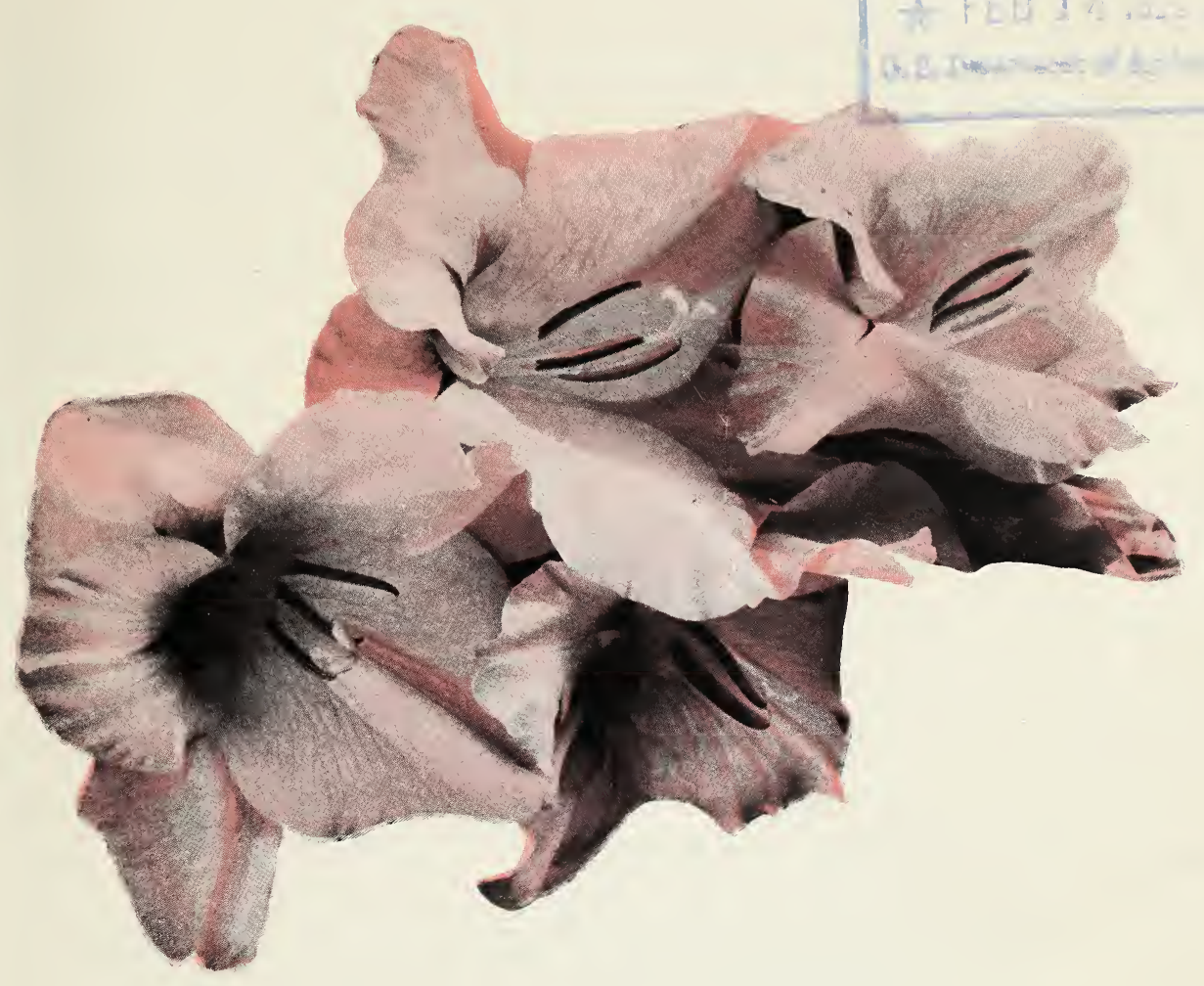

\section{"GLADIOLUS FARM" W. L. CRISSEY BORING OREGON}




\title{
An Invitation
}

You are cordially invited to visit "Gladiolus Farm" at any season most convenient. It is 23 miles east of Portland, on MAIN BULL RUN ROAD, and adjoins Dodge Park. Leave Gresham on the Powell Valley Road, and watch for Bull Run and Farm signs. The picturesque location of the Farm would in itself well repay the trip-but-

In early spring there are the tulips and daffodils, in May and June the peonies and irises, in midsummer the gladioli, and in fall countless interesting things.

\section{Instructions for Ordering}

Bulbs and irises are sent prepaid at prices quoted; perennial plants go with transportation charges added or collect. Gladioli and irises are sent at any time after January 1st; plants any time after February 15th if weather conditions permit, but WHENEVER DELIVERY IS DESIRED, EARLY ORDERING IS RECOMMENDED TO GET THE BENEFIT OF COMPLETE ASSORTMENT.

Remittance or bank reference should accompany order. Either check, postal or express order is acceptable, or for amounts up to $\$ 1.00$, two-cent stamps will be taken.

The greatest care is taken to supply stock true to name, and an effort is always made to satisfactorily adjust any error in this regard, but in accordance with the custom of the trade, no guarantee is given.

Make remittances payable to

\author{
W. L. CRISSEY, \\ "Gladiolus Farm," \\ R. F. D. 1, Boring, Oregon.
}

Long distance phone, Farmers 343, Gresham Exchange.

Telegraph address, care Gresham Telephone Exchange. 
G ardening is surely the most interesting occupation in all the wide world. The extensive gardens at "Gladiolus Farm" sprang from a most modest beginning-just a few dozen gladioli which produced such large and perfect flowers at blooming time, such clean and healthy bulbs at harvest, that it seemed just natural to devote the place to flower growing.

The Farm is located in the foot hills of majestic Mount Hood, a little plateau with friable, splendidly drained soil. Two hundred and fifty feet below, framed by giant firs which count their age in centuries, are the Sandy and Bull Run Rivers, most arresting feature in one of the loveliest landscapes to be found in the Pacific Northwest.

Gladioli of the newest and handsomest sorts are the main crop at "Gladiolus Farm" and the bulb house lined with trays which reach from floor to ceiling, each with its burden of bulbs so full of summer promise, would enthuse any flower lover.

BUT YOU CAN'T HAVE A REAL GARDEN WITH JUST ONE FLOWER. No matter how supremely attractive it may be, so now my flower fields contain scores of other interesting occupants, beginning with a grand display of tulips (the early ones and the great big, long-stemmed Darwins so much sold as cut flowers in exclusive shops) and thousands of narcissi, crocuses and the brilliant Spanish and Dutch bulbous irises which last so long in garden or vase. Then come the German irises in every conceivable shade of blue and lavender and royal purple and orchid tints-they dominate the garden in June. Next are the peonies and from July on the gladioli, so aptly termed "Torches of Beauty."

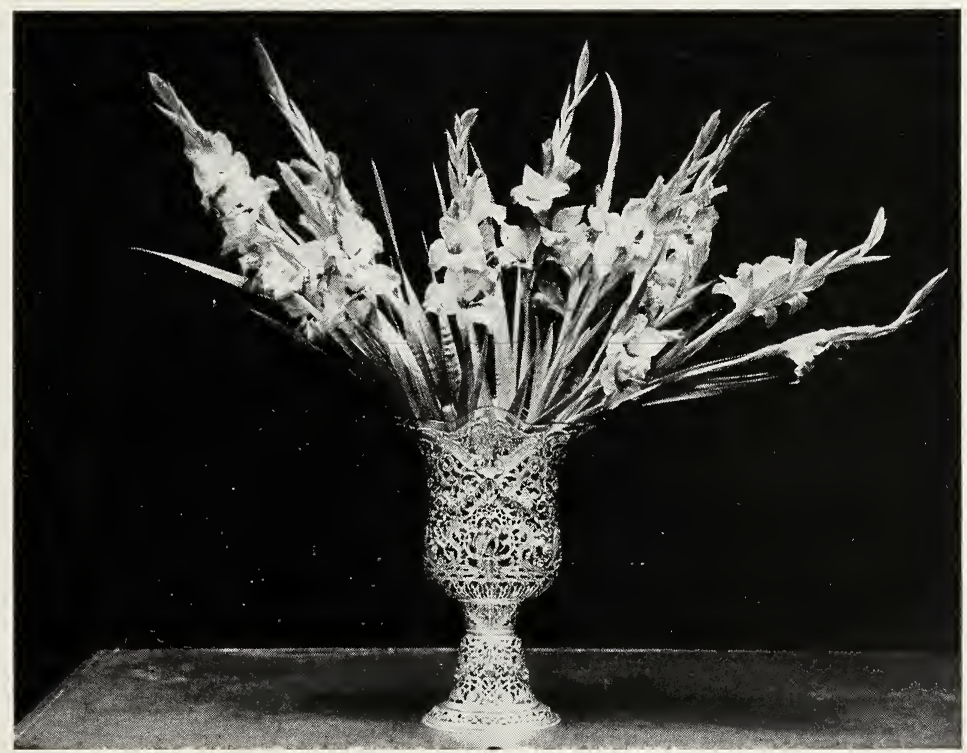




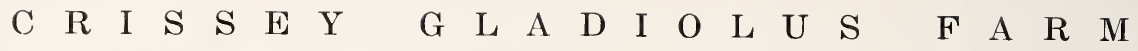

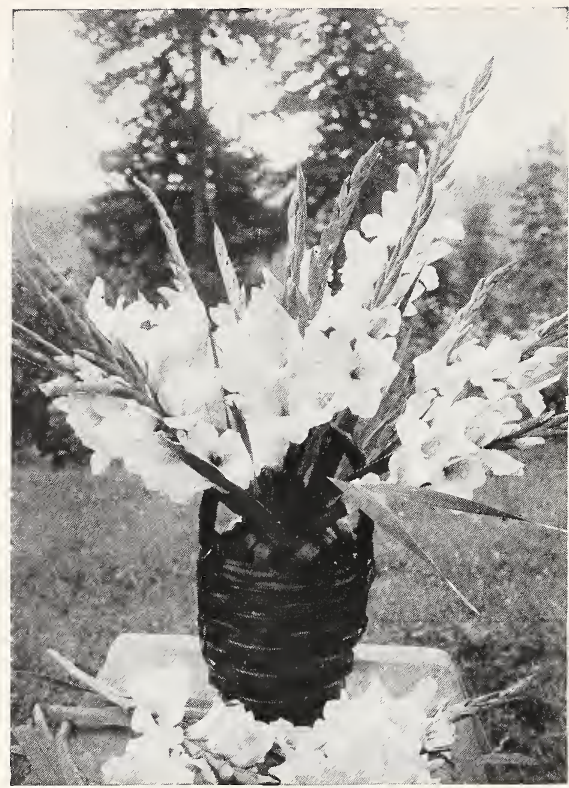

Baskets are delightful receptacles for Gladioli

And always, whether it be spring, summer or fall, there is the fascinating background of perennials, ranging from the graceful little prostrate rock plants to imposing hollyhocks, delphiniums and asters. Special attention has been paid to the fall flowers, which always seem doubly acceptable as the season wanes.

\section{GLADIOLI}

I'm going to list the "glads" first, irrespective of alphabet or anything else, as they are my specialty and really unapproachable in their infinite range from delicate to brilliant color, and general usefulness, whether employed indoors or out.

\section{THEIR EASY CULTURE}

Plant the bulbs whenever the earliest vegetable gardens are made, and at intervals until early

summer, for this gives a succession of bloom covering four months or more. Set the bulbs a good five or six inches deep; they will support their flower stalks better and be generally more satisfactory than with shallow planting. Put them four to six inches apart in the row, the rows just far enough apart to permit cultivation. Any good garden soil will do, but take pains to see that manure has not been freshly applied, as they resent that. Clean cultivation and lots of water are appreciated, but the water is the less essential of the two. A sunny location is most necessary of all.

\section{FOR NEW GROUNDS}

To fill in the bare spots in new shrubbery or perennial plantings use gladioli generously; plant them also in the back yard where you can cut for friends and house without compunction. When you arrange them in your rooms, choose clear glass container's for the delicate colors; the more decided colors take on additional beauty through the repetition of the flower tone in vase or jug. A heavy glass frog is indispensible in arranging gladioli in low bowls.

\section{AT HARVEST TIME}

In this climate, dig about November 1st, cut the stems off right at the bulb immediately, then dry a few days until the old withered corm is readily twisted off. Put the cleaned bulbs in cool, frost-proof nook of your basement, but not until thoroughly dry, and you will find them in perfect condition for another year's duty in your garden. 


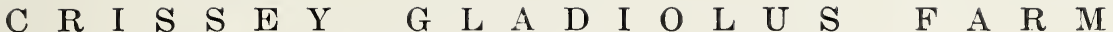

The following list includes many of the finest varieties originated in this country and Europe, and each and every one is worth while. Of course there are aristocrats among them, and for these you have to pay as you would for a rich tapestry or a thoroughbred collie.

American Beauty--True American Beauty rose color, relieved by a soft yellow throat. Often a full dozen immense flowers are open at one time, making a single spike a whole bouquet. $\$ 1.00$ each, $\$ 10.00$ the dozen.

Anna Eberius-Beautiful flowers of deep, velvety purple. One of the finest dark flowers. 25 cents each, $\$ 2.50$ the dozen.

Blue Jay-Soft blue with markings of deeper tone, and white splotched throat, give an iris-like effect. Very tall and large. True Blue Jay is rare. 40 cents each, $\$ 4.00$ the dozen.

Butterfly-Brilliant salmon, throat doubly blotched with deep maroon, the whole appearance reminding one of a butterfly in flight. Extra fine in garden masses. 15 cents each, $\$ 1.50$ the dozen, $\$ 9.00$ the hundred.

Charlemagne-A French variety of exceptional coloring. Sunrise red, with deeper pencilings. A majestic spike. 35 cents each, $\$ 3.50$ the dozen.

D. J. Whitney-Exquisite salmon flesh. Will command attention in any collection, no matter how expensive. $\$ 1.00$ each, $\$ 10.00$ the dozen.

Etendard-French growers never contributed a handsomer flower than this, with its blush petals, the lower ones bearing vivid crimson blotches outlined in clear yellow. 40 cents each, $\$ 4.00$ the dozen.

Bengal Tiger-Old rose ground with barbaric striping in darker shades. A high - class exhibition variety of very recent introduction. $\$ 2.00$ each, $\$ 20.00$ the dozen.
Conspicuous-Light blue, yellow blotch with dark border. A charming sort. 25 cents each, $\$ 2.50$ dozen.

Crimson Glow-The name fitly describes the color. Flowers often seven inches in diameter. 50 cents each, $\$ 5.00$ the dozen.

David Starr Jordan-One of the best reds ever grown at Gladiolus Farm. Usually branches, giving unusually long display in the garden. 25 cents each, $\$ 2.50$ the dozen.

E. J. Shaylor-Pure deep rose pink. Has award of the English Horticultural Society to its credit. 50 cents each, $\$ 5.00$ the dozen.

Evelyn Kirtland-A grand coral pink, enhanced by deeper shade on lower petals. Wide open, finely shaped flowers on long spike. 20 cents each, $\$ 2.00$ the dozen.

Golden Measure-The greatest novelty of all, and the only large-flowered, rich golden yellow gladiolus yet achieved. Tall and vigorous, often throwing two spikes from one bulb. The price is justified by its beauty and uniqueness. $\$ 3.50$ each.

Golden West-Striking orange red, a new shade in gladioli. 15 cents each, $\$ 1.50$ the dozen.

Goliath-A red that is almost black in its intensity. 25 cents each, $\$ 2.50$ the dozen.

Gretchen Zang-Soft pink, melting into scarlet on lower petals. Late planting of this sort gives choicest blooms. 15 cents each, $\$ 1.50$ the dozen.

Halley-Lovely coral, with yellow throat. Very early. 10 cents each, $\$ 1.00$ the dozen, $\$ 6.00$ the hundred. 


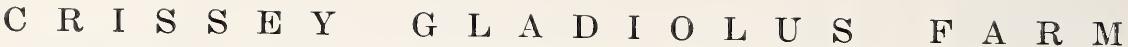

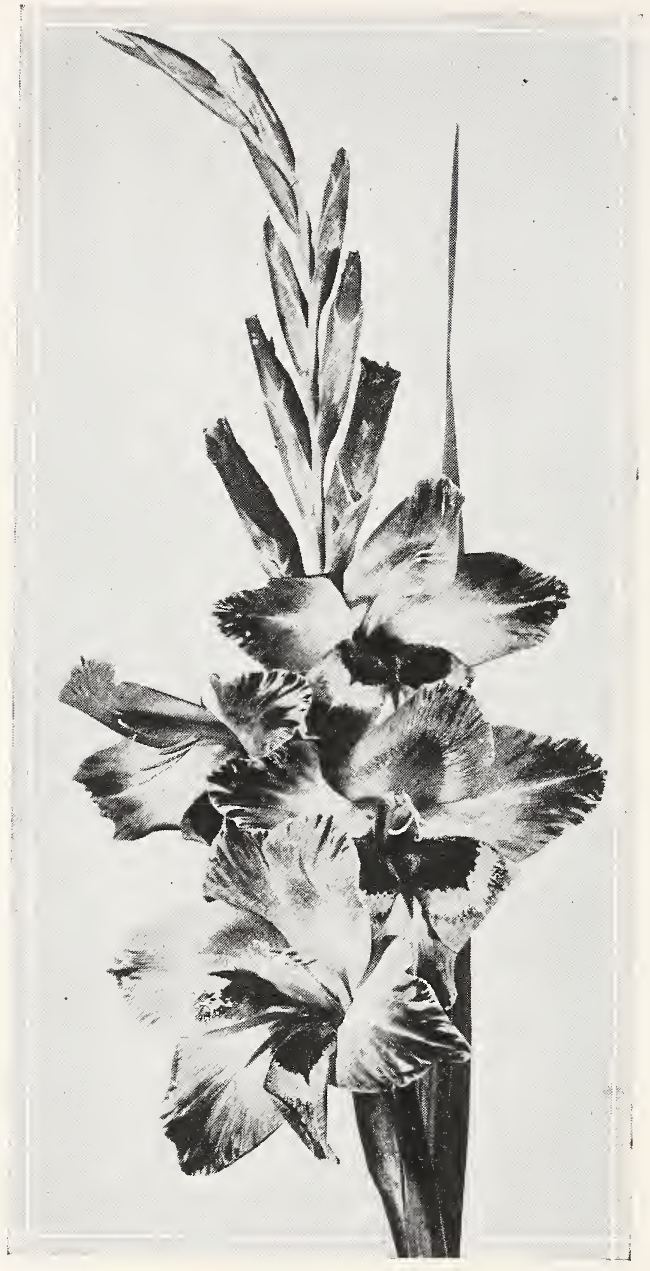

Herada-Clear mauve, as charming as it is unusual. Flowers very large. 20 cents each, $\$ 2.00$ the dozen.

Jane Dieulafoy-Cream with chestnut throat, spikes graceful and branched. 15 cents each, $\$ 1.50$ the dozen.

Lily Lehman-White, flushed pink. Flowers lily shaped. 15 cents each, $\$ 1.25$ the dozen.

Louise-Immense flowers of clear lavender, deeper throat. Try this arranged with pink physostegia, from your perennial garden. Fxquisite. 75 cents each, $\$ 7.50$ dozen.

Loveliness-Charming combination of cream, merging into apricot and rose. 20 cents each, $\$ 2.00$ the dozen.

Le Marchael Foch (Holland origination-Immense flowers of pale rose pink, many open at one time. The most discussed of late European introductions. 50 cents each, $\$ 5.00$ the dozen.

Marshall Foch (American introduction)-Soft salmon pink, almost a self color, and very beautiful. First-class certificate of merit by Massachusetts Horticul t u r a 1 Society. 50 cents each, $\$ 5.00$ the dozen.

Mary Fennel-Soft lavender, merging into creamy yellow toward the center. 20 cents each, $\$ 2.00$ the dozen.

Just a spike of "Butterfly"

Majestic-Clear orange pink with creamwhite mid-rib in each petal. Flower large and open. Exceptionally pure color tone. 60 cents each, $\$ 6.00$ the dozen.

Mrs. H. E. Bothin-Delicate pink with crimson throat, the whole an effect that arrests attention wherever exhibited. 50 cents each, $\$ 5.00$ the dozen.
Jack London-Light salmon with orange flame stripes - yellow throat. Large spikes and flowers. Extra 50 cents each, $\$ 5.00$ the dozen.

Mrs. John R. Walsh-Another pink and crimson flower, but of such vigor, size and beauty that it is in a class by itself. $\$ 1.50$ each, $\$ 15.00$ the dozen. 
C R I S S E Y G G L A
Mrs. Cothran-The blending of ashes of
roses and crushed strawberry aproses and crushed strawberry apshades. 25 cents each, $\$ 2.50$ dozen.

Mrs. Dr. Norton-White, suffused with melting pink. Sulphur yellow blotches on lower petals are dotted. with pink. 50 cents each, $\$ 5.00$ the dozen.

Mrs. W. E. Fryer-Orange red, very brilliant. 20 cents each, $\$ 2.00$ dozen.

Mrs. William ..Kent-Imagine a fawn flower, shading to ashes of roses. Strong growing and prolific sort. 30 sents each, $\$ 3.00$ the dozen.

Mrs. Frank Pendleton-Pink with crimson blotch, like an immense Lady Washington geranium. 15 cents each, $\$ 1.50$ the dozen.

Muriel-Soft lavender blue, with deeper blotch. This is finest blue of all for garden effect. New and extra choice. $\$ 1.00$ each, $\$ 10.00$ dozen.

Myra-A new Primulinus that is properly termed a giant. Deep salmon and yellow combine beautifully in the great hooded flower. 50 cents each, $\$ 5.00$ the dozen.

Nora-An European blue, displaying darker marking on lower petals. 30 cents each, $\$ 3.00$ the dozen.

Norma D. Childs-Palest pink with lemon yellow throat. 30 cents each, $\$ 3.00$ the dozen.

Orange Giory-Brilliant orange pink, heavily ruffled petals, and massive flower. 35 cents each, $\$ 3.50$ the dozen.

Panama-Soft deep pink, with frosted sheen in sunlight. Strong grower and desirable in every way. 10 cents each, $\$ 1.00$ the dozen, $\$ 6.00$ the hundred.

Peace-Stately white, with lilac feathered throat. Fine late flower. 15 cents each, $\$ 1.50$ the dozen.

Pink Perfection-Apple - blossom pink. Spikes are frequently curved, permitting artistic vase arrangement. 15 cents each, $\$ 1.50$ the dozen.

Pride of Hillegom-Many consider this the finest scarlet. A slight marking of white intensifies the color. 30 cents each, $\$ 3.00$ the dozen.
Primulinus Hybrids-Soft yellows in combination with orange, pink, terra cotta, rose and similar shades, make these distinct. Flowers are of moderate size, hooded in shape and often heavily ruffled. The strain offered has won prizes at many flower shows. Plant generously and use in clear glass bowls. $\$ 1.25$ dozen, $\$ 7.50$ hundred.

Prince of India-The aristocrat of the garden. A background of ashes of roses, markings of dull blue and smoke gray combine in subtle harmony. 50 cents, $\$ 5.50$ dozen.

Prince of Wales-Softest salmon, with an apricot undertone like the Ophelia rose. 15 cents each, $\$ 1.50$ the dozen.

Principine-Crimson with white throat. A gorgeous "high light" for the garden, especially in masses. 10 cents each, $\$ 1.00$ dozen, $\$ 6.00$ hundred.

Purple Glory-Huge ruffled flower of richest purple, blotched deeper. Took highest award at the International Gladiolus Show 1921. $\$ 1.50$ each, $\$ 15.00$ the dozen.

Rosella-Big flowers of true cerise, stained white and purple. 20 cents each, $\$ 2.00$ the dozen.

Rouge Torch-Creamy petals with crimson velvet tongue in throat. Slender, graceful spikes. A large vase of them gives the impression of creamy pink. 15 cents each, $\$ 1.25$ dozen, $\$ 7.50$ hundred.

Red Emperor-Bright scarlet of glowing quality. 25 cents each, $\$ 2.50$ the dozen.

Red Amaryllis-Visitors always surrounded the big amber vase which held Red Amaryllis at my largest 1921 exhibit. The flowers are large. 25 cents each, $\$ 2.50$ the dozen.

Rose Ash-Ashes of roses, exquisite beyond description. Very generally sold at $\$ 10.00$ each, but a large stock enables me to offer at just half that. $\$ 5.00$ each, six for $\$ 25$.

Schwaben-Immense spikes and immense flowers of waxy yellow. They are impressive as lilies. 15 cents $e \mathrm{ach}$, $\$ 1.50$ the dozen. 


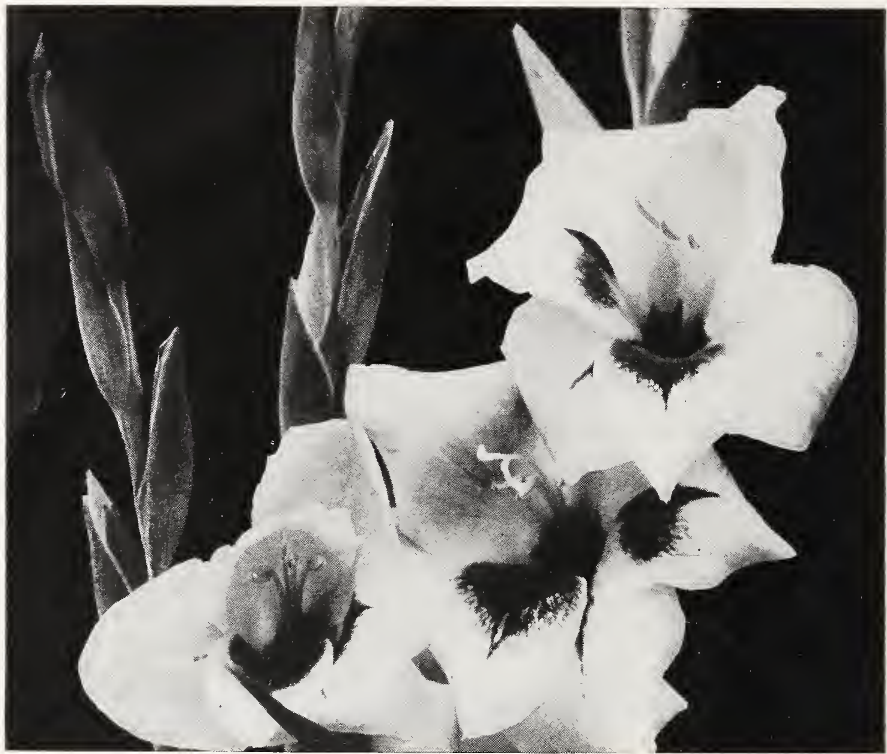

Cream

petals with

a tongue

of vivid

crimson

Topaz-A lovely Primulinus type, with large flower blending salmon and buff shades. 30 cents each, $\$ 3.00$ the dozen.

Violet Glory-Rich deep violet, ruffled and massive. 50 cents each, $\$ 5.00$ the dozen.

White Glory-White with iris blue lines in throat. The bloom is ruffled. 35 cents each, $\$ 3.50$ the dozen.

War-Glowing crimson, best of its class. Seen in the sunlight, a bed of these is not soon forgotten. The color fits well with autumn decorations. Late flowering. 15 cents each, $\$ 1.50$ dozen, $\$ 10.00$ hundred.
White Cluster-White with soft rose spot in throat. The finest white at reasonable price. 15 cents each, $\$ 1.50$ the dozen.

Willy Wigman-Cream petals and rose blotched throat. 15 cents each, $\$ 1.50$ the dozen.

Named Mixed-Made up of remnants and accidental mixtures, many of the most desirable kinds are represented in this. An exceptional value. 75 cents the dozen, $\$ 4.50$ the hundred.

\section{TULIPS, DAFFODILS AND OTHER THINGS}

I have a fine stock of Dutch bulbs (but grown in my own gardens) for fall planting, which include the early flowering tulips in crimson, yellow and scarlet; big late Darwins in two tones of pink, scarlet and heliotrope; the daffodils and narcissi of most recent introduction, such as the wonderful King Alfred and Van Waveren's Giant. There are also thousands of Spanish and Dutch irises, which come from bulbs, and in the most brilliant blues, lavender and yellow.

If interested, ask for the fall list, ready about September. 


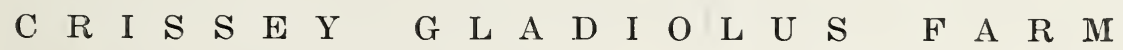

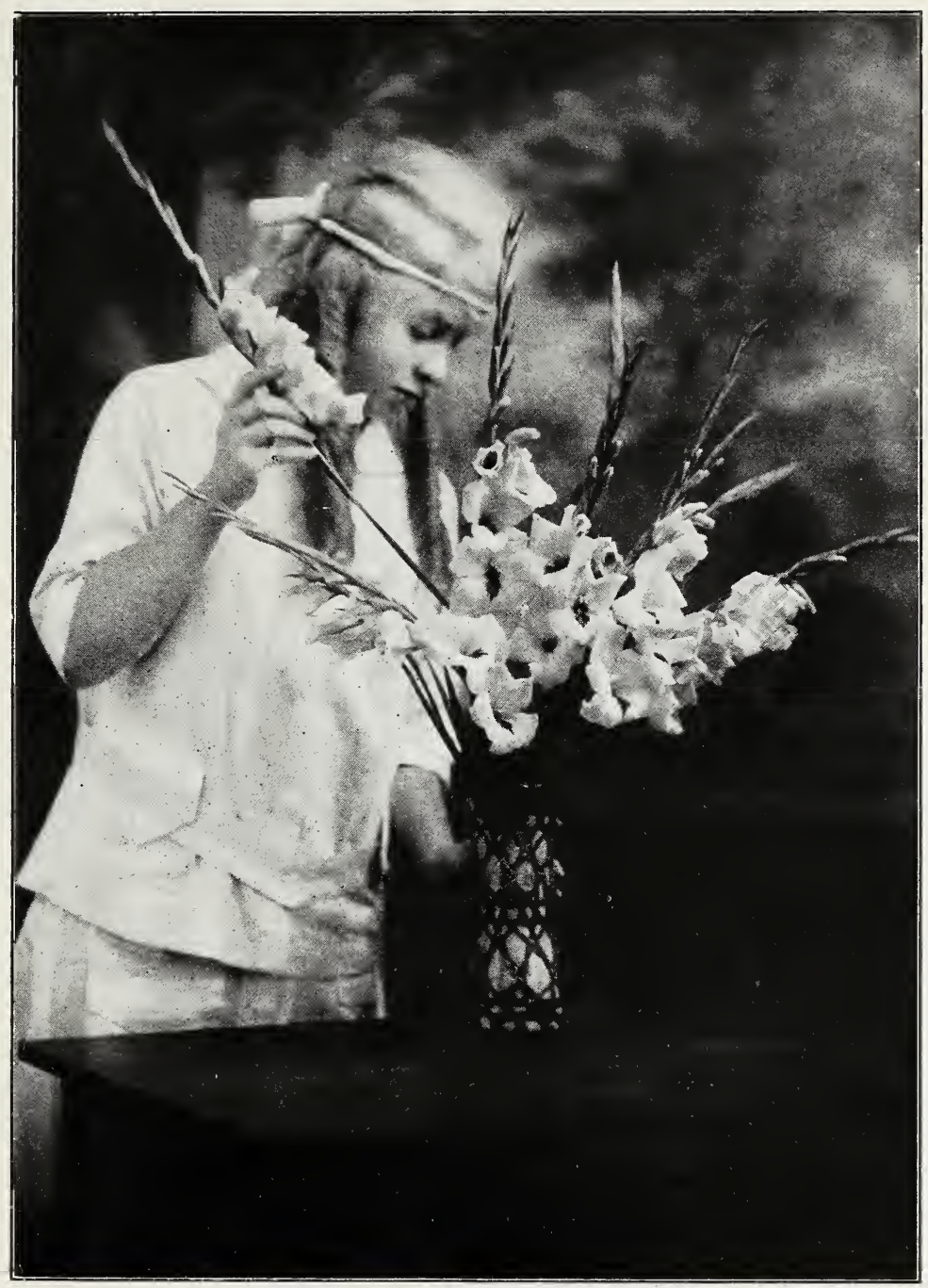

Gladioli are graceful in the extreme when properly arranged. There is a type to suit almost every vase. 


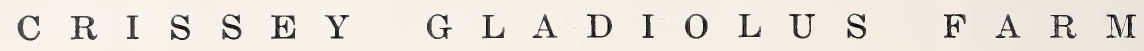

\section{GIFT BOXES OF BULBS AND FLOWERS}

Bulbs are gifts truly appreciated by the possessor of even the most modest garden. I make up attractive boxes of any desired value from $\$ 1.50 \mathrm{up}$, and mail with the giver's card at any desired date in season. In September and October the contents would be tulips and narcissus bulbs; from December 15th to May 1st the box would be filied with choice gladiolus bulbs. For the holiday season the container is decorated in water colors.

The flowers ship perfectly to points within three hundred miles of Portland. A dozen cut gladioli make an ideal gift for an invalid or convalescent, or to mark an anniversary. From July 1st to October 1st I am prepared to send such boxes at $\$ 2.00$ and $\$ 3.00$, charges prepaid within three hundred miles of Portland. Donor's card is included upon request. Handsome tulips are available in May.

Are you giving a party in Portland or nearby? Quantities of desirable flowers are always available at the farm, and at extremely reasonable prices. Drive out and get them, or telephone Gresham 343. They can be expressed to the city in early morning.

\section{PHLOX}

One of the finest mid-summer flowers. Try half a dozen or more of a single sort as a feature of your garden. Delightful fragrance.

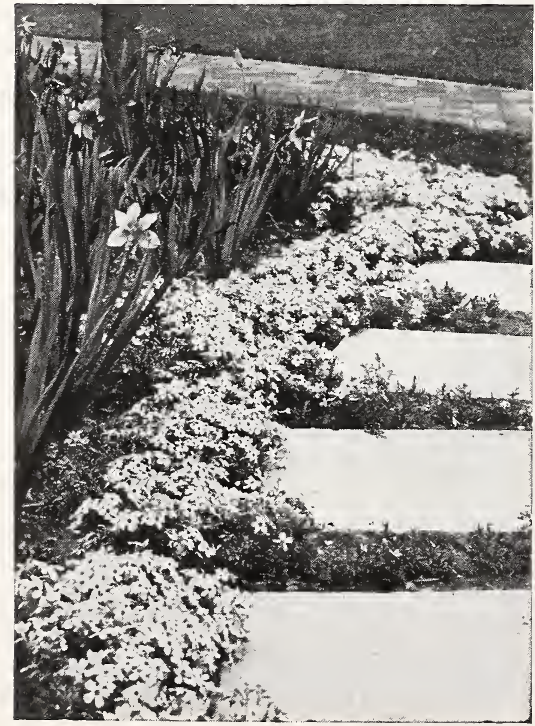

Phlox sublata is a natural border for flagstone path or steps.
Miss Lingard-Very early white. Often blooms several times a season. 35 cents each, $\$ 3.50$ the dozen.

Mrs. Jenkins-A fine late white. 35 cents each, $\$ 3.50$ the dozen.

Panthenon-Deep, true pink, immense flowers and truss. Best of all for garden pictures. 35 cents each, $\$ 3.50$ the dozen.

The President-Exquisite creamy pink; extra fine. 40 cents each, $\$ 4.00$ the dozen.

Sublata, or "Moss Pink"-Trailing mosslike foliage, completely obscured in the spring by a sheet of lilac flowers. Increases rapidly. 25 cents each, $\$ 2.50$ the dozen.

Physostegia - The pretty flowers are borne on upright branched stems in late spring. Cuts well. Pink, with soft lavender cast. 35 cents each, $\$ 3.50$ the dozen.

White, 35 cents each, $\$ 3.50$ dozen. 


\section{LILIES}

Annunciation or St. Joseph's Lily-Tall growing, pure white trumpet with fine fragrance. Increases rapidly. 35 cents each, $\$ 3.50$ the dozen.

Auratum "Gold Banded Lily of Japan"Immense white flowers, rather flaring in shape, spotted golden brown and with a gold band down the center of each petal. 50 cents each, $\$ 5.50$ the dozen.

Regale or Myriophyllum-Grandest of all hardy lilies. Its creamy trumpet is tinged soft brown outside, the petals suffused toward the tip with pale pink. Throat is lemon yellow, and fragrance all that can be desired. NEW. $\$ 1.00$ each, $\$ 10.50$ the dozen.

Speciosum Rubrum-Recurved white petals dotted with rich red. 50 cents each, $\$ 5.50$ the dozen.

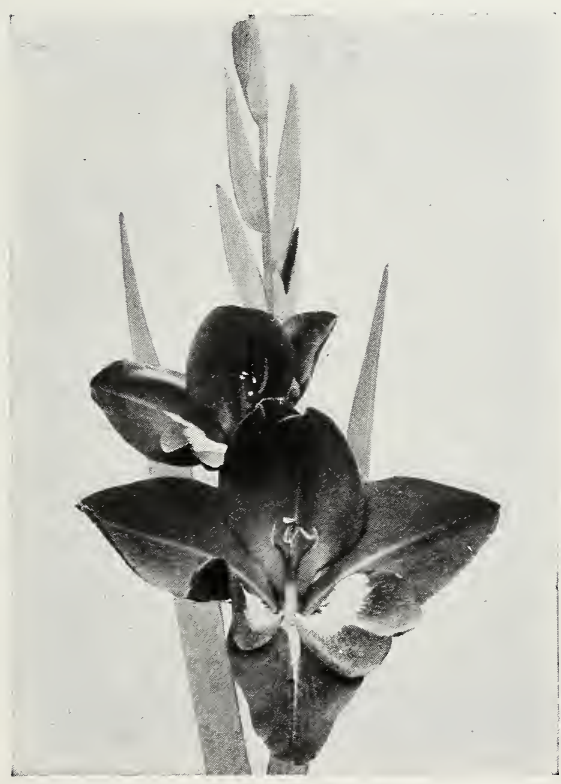

This flower was over six inches in diameter.
Lupin-Three to four-foot spikes of handsome flowers in May and June. Excellent for naturalizing, as one species of blue is native here. Rose shades, very beautiful. 40 cents each, $\$ 4.00$ the dozen. Blue from light to dark. 25 cents each, $\$ 2.50$ the dozen.

Myosotis-"Royal Blue"-This deep blue forget-me-not makes a wonderful sheet of spring color, flowering very freely, and much finer than the common pale blue. 25 cents each, $\$ 2.50$ the dozen.

Pansies-Raised from the highest grade (and most expensive) seed obtainable. Bewildering range of color and markings. Immense flowers. 75 cents the dozen, $\$ 4.50$ the hundred.

Penstemon Murrayanus-A unique variety with amber-scarlet tubes. 30 cents each, $\$ 3.00$ the dozen.

\section{PRIMROSES}

English-These are perfectly hardy on the Pacific Slope, and among the earliest and loveliest of spring messengers.

Choicest Mixed - Including rose, yellow, auricula eyed, orange and other colors. Some are edged with gold. Not sold in separate color. 25 cents each, $\$ 2.50$ the dozen.

Double Lavender - Like miniature roses. Beautiful for corsage bouquets. 35 cents each, $\$ 3.50$ the dozen.

Blue-A high-grade novelty, raised expressly for me by a primrose specialist on Puget Sound. Flower is a true deep blue. 50 cents each, $\$ 5.00$ the dozen. 


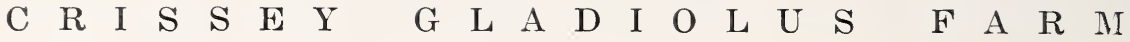

\section{GERMAN IRISES}

No other flower is attaining the vogue accorded the iris, and with good reason, for the plants are hardy and grown with the greatest ease, the flowers as exquisitely colored and wonderfully shaped as the choicest hot-house bloom. Irises are most effectively planted in quantity, and are especially good to naturalize at the edge of woodlands or to border an informal path.

Irises increase rapidly and soon form handsome clumps. They are transplanted in early spring or early fall with equal certainty of thriving in their new locations, but fall planting gives greater assurance of flowers the first season. The roots should not be set too deep-a couple of inches of soil to cover is sufficient. They require good drainage and prefer full sunshine. Manure is particularly distasteful to them and often fatal, but bone-meal and air-slacked lime are excellent. June is the month of most prolific bloom.

Alcazar-Standards light blue violet, falls rich purple. Extra fine. \$1.25 each, $\$ 12.50$ the dozen.

Archeveque-Velvety violet purple, distinctive in any collection. $\$ 1.00$ each, $\$ 10.00$ the dozen.

Albicans (Princess of Wales)-A large white flower of fine form. 40 cents each, $\$ 4.00$ the dozen.

Catarina-Huge flowers of soft silvery lavender, on very tall stems. Delicious fragrance. Multiplies slowly. $\$ 1.00$ each, $\$ 10.00$ the dozen.

Caprice-Claret red, superior for landscape effects. 35 cents each, $\$ 3.50$ the dozen.

Crusader-A beautiful intense clear blue, standards a little lighter than falls. Free blooming and of excellent substance. $\$ 3.00$ each.

Flavescens-Soft yellow throughout. Free bloomer. 25 cents each, $\$ 2.00$ the dozen.

Fro-Standards orange, falls mahoganythe best of its coloring. 50 cents each, $\$ 5.00$ the dozen.

Germanica-A rich deep purple flower, especially good for naturalizing and massing. 25 cents each, $\$ 1.50$ the dozen, $\$ 8.00$ the hundred.

Her Majesty-Beautiful deep pink in general effect. 35 cents each, $\$ 3.50$ the dozen.

Isolene-Standards silvery lilac, falls purplish old rose. One of the best new ones. $\$ 1.00$ each, $\$ 10$ dozen.

Juniata-Clear deep blue, tall and vigorous. 50 cents each, $\$ 5.00$ dozen.

King of Iris-Standards clear yellow, falls rich maroon margined gold; a very brilliant contrast. 50 cents each, $\$ 5.00$ the dozen.

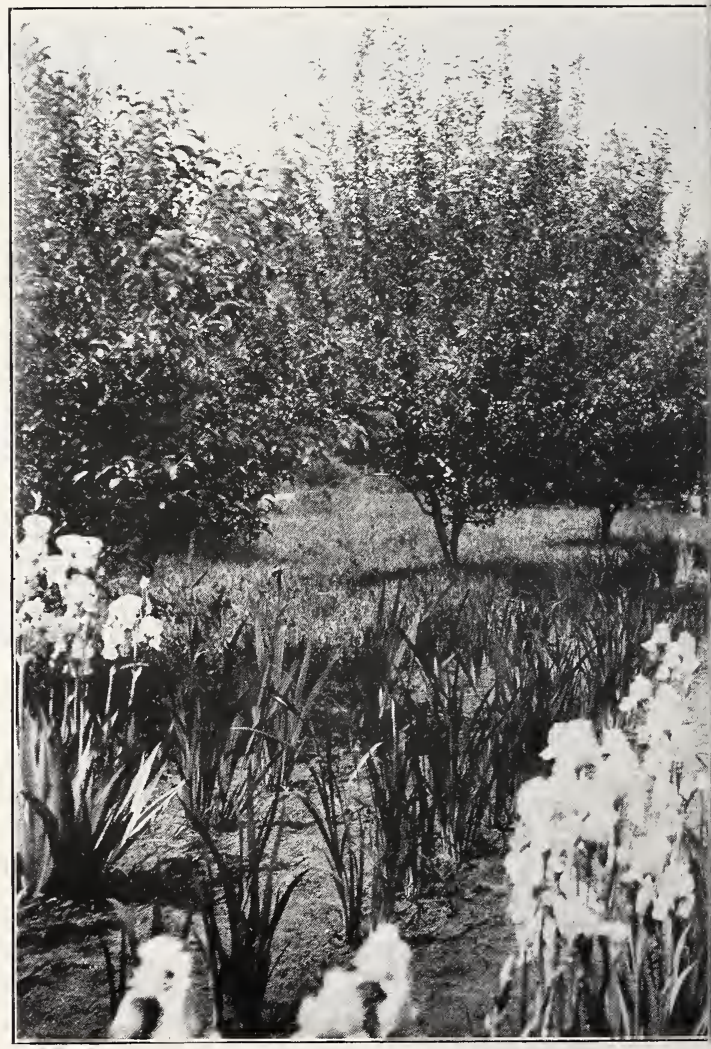

One of my Iris

Lohengrin-A pink mauve, which is very beautiful. 50 cents each, $\$ 5.00$ the dozen. 


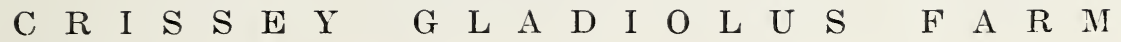

Lord of June-Standards lavender blue, falls light violet blue. A frequent prize-winner. $\$ 5.00$ each.

Liberty-Rich blue, a trifle deeper than Juniata. 50 cents each, $\$ 5.00$ the dozen.

Loreley-Standards light yellow, falls purple merging into canary. Standards often splashed purple. 35 cents each, $\$ 3.50$ the dozen.

Maori King-Standards bright yellow, falls crimson, bordered gold. Late and rather dwarf. 40 cents each, $\$ 4.00$ the dozen.

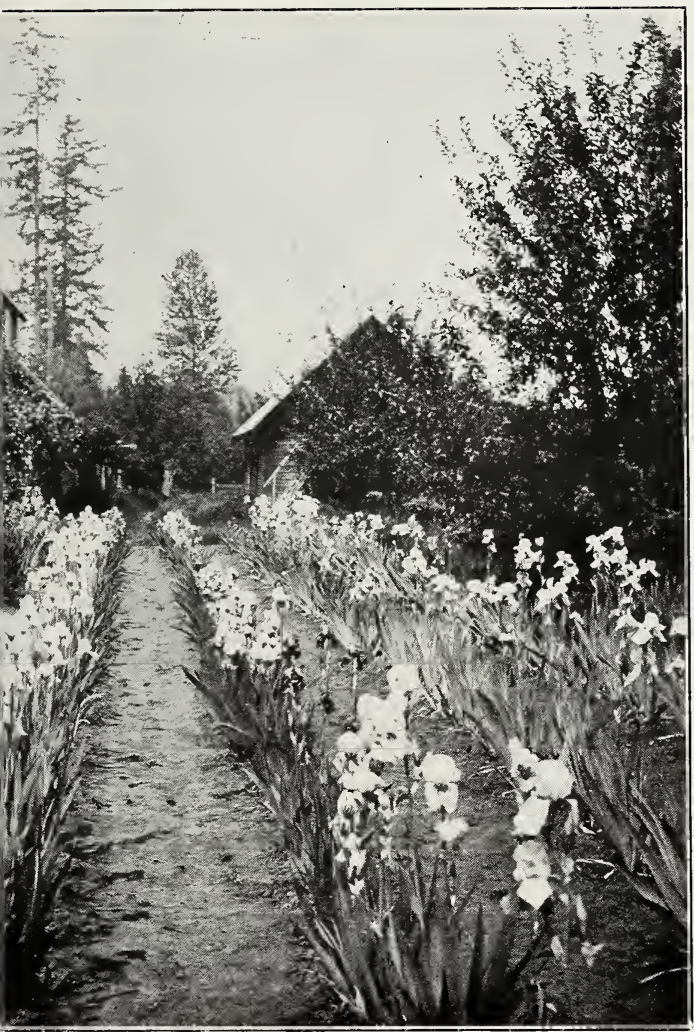

dens in June

Madam Chereau-White, daintily edged with lavender blue. 25 cents each, $\$ 2.00$ the dozen.
Madam Pacquette-Whole flower of a rosy claret shade, very fine in a mass. 30 cents each, $\$ 3.00$ dozen.

Mrs. Neubronner-One of the deepest yellows. 30 cents each, $\$ 3.00$ dozen.

Monsignor-Standards satiny violet, falls crimson purple, margined lighter. 50 cents each, $\$ 5.00$ the dozen.

Monsieur Chereau-Bronze and old gold, with a glowing quality hard to describe; dwarf, 35 cents each, $\$ 3.50$ the dozen.

Ma Mie-Clear white, with most delicate frill of pale lavender. 40 cents each, $\$ 4.00$ the dozen.

Nibelungen-Standards fawn with olive tint; falls purple, margined fawn. 40 cents each, $\$ 4.00$ the dozen.

Ossian-Standards light yellow, falls light claret. 35 cents each, $\$ 3.50$ dozen.

Perfection-Standards old blue, falls deep velvety purple, particularly fine form. 50 cents each, $\$ 5.00$ dozen.

Prosper Laugier-Finest of the bronzes, very rich. 75 cents each, $\$ 7.50$ the dozen.

Princess Victoria Louise-Standards are primrose, falls plum edged primrose. 50 cents each, $\$ 5.00$ dozen.

Pallida Dalmat'ca-Big flowers of a lovely silvery lavender shade on very tall stems. One of the best for massing. 35 cents each, $\$ 3.50$ the dozen.

Parisiana-Standards lavender pink, falls cream edged and stippled lavender. 75 cents each, $\$ 7.50$ dozen.

Pseudo A.coris-Fol age two feet in length, almost tropical in luxuriance. Small flowers of brilliant yellow. Succeeds in either marshy or well drained situation. Superior as a background in the border. 35 cents each, $\$ 3.50$ the dozen.

Rhein Nixe-Standards pure white, falls deep violet bordered with white. 50 cents each, $\$ 5.00$ the dozen.

Sherwin Wright-Golden yellow throughout: no markings. 50 cents each, $\$ 5.00$ the dozen.

Silver King-Not pure white, but lovely older sort. 25 cents each, $\$ 2.00$ the dozen.

Standard Bearer-Rich claret shade, unusually effective in the garden. Tall. $\$ 1.00$ each, $\$ 10.00$ the dozen.

White Knight-Standards and falls both of pure milk white. $\$ 1.00$ each, $\$ 10.00$ the dozen. 


\section{C $\quad \begin{array}{lllllllllllll} & \text { I } & \text { S } & \text { S } & \text { E } & \text { Y }\end{array}$ \\ $\begin{array}{lllllllllllllllll}\text { G } & \text { L } & \text { A } & \text { D } & \text { I } & \text { O } & \text { L } & \text { U } & \text { S }\end{array}$ \\ GENERAL LIST OF PERENNIALS, HARDY BULBS AND SHRUBS}

F A R M

Having a perennial garden is much like renewing old friendships each year, for the plants may be depended upon to return regularly, with added beauty, so long as they are properly cared for. Early spring setting is important if you want a good effect the first year.

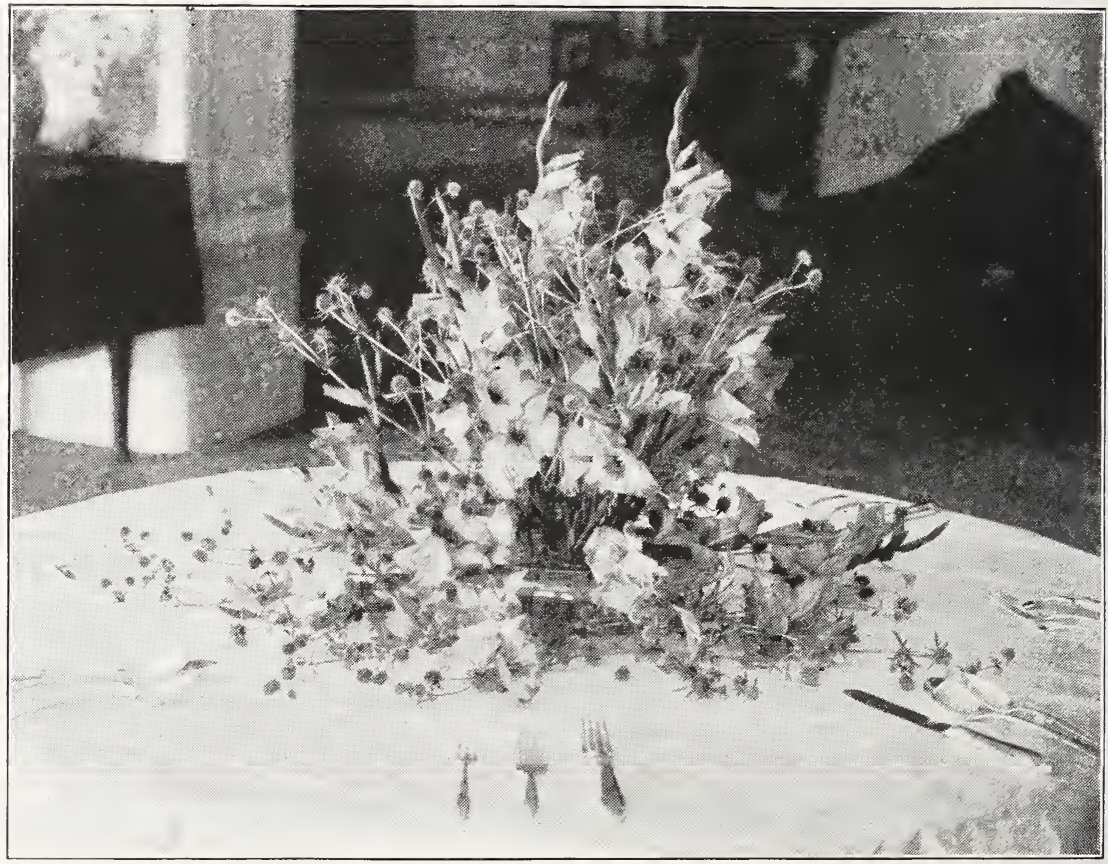

\section{Eryngium Oliveranum with Halley Gladioli}

Alyssum Saxatile Compactum-Silvery foliage, bright yellow flowers almost enveloping the plant. 25 cents each, $\$ 2.50$ the dozen.

Anchusa Italica-Dropmore-The flowers are gentian blue, borne in great quantities upon a loosely branching plant 4 feet in height. 35 cents each, $\$ 3.50$ the dozen.

Asters-Feltham Blue-Rich blue, the best of its color. Very free flowering. Four feet tall. 35 cents each, $\$ 3.50$ the dozen.

Gracillimas-Latest of all. Tiny white flowers, changing to soft blue and almost covering the plant. Seldom seen. 50 cents each, $\$ 5.00$ the dozen.
Praecox-Heliotrope purple, glowing orange center. Early autumn. Four feet. 40 cents each, $\$ 4.00$ the dozen.

Robert Parker - Lavender flowers with gold center. Early fall. 35 cents each, $\$ 3.50$ the dozen.

St. Edgwin-A beautiful pink aster, borne in graceful sprays. Early. Four feet. 35 cents each, $\$ 3.50$ the dozen.

Sub-coerulescens-Violet blue flowers in June and July, freely produced. Choice cutting material. One foot. 25 cents each, $\$ 2.50$ the dozen. 


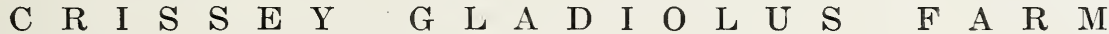

Bellis Monstrosa-A giant form of the English hardy daisy, with individual flowers the size of a dollar. In cheerful mixture of red, pink and white. 25 cents each, $\$ 2.50$ the dozen.

Buddleia Magnifica-"Butterfly Bush"Bears graceful racemes of purple flowers of pleasing fragrance all summer. Grows 10 feet or more, but should be rigorously pruned. Fine plants, 75 cents each.

Campanula Persicifolia-"White Peach Bells"-The purity and grace of these flowers are irresistible when planted en masse. 30 cents each, $\$ 3.00$ the dozen.

Campanula-Canterbury bells of cup and saucer type, in lovely pink, with an occasional carmine flower. Not a true perennial. 15 cents each, $\$ 1.50$ the dozen.

Centaurea Dealbata-Beautiful and long stemmed flowers of lavender-rose, very lasting when cut. Four feet. $A$ rare plant, not easily propagated. Mine are specimens four years old. $\$ 1.00$ each, $\$ 10.00$ dozen.

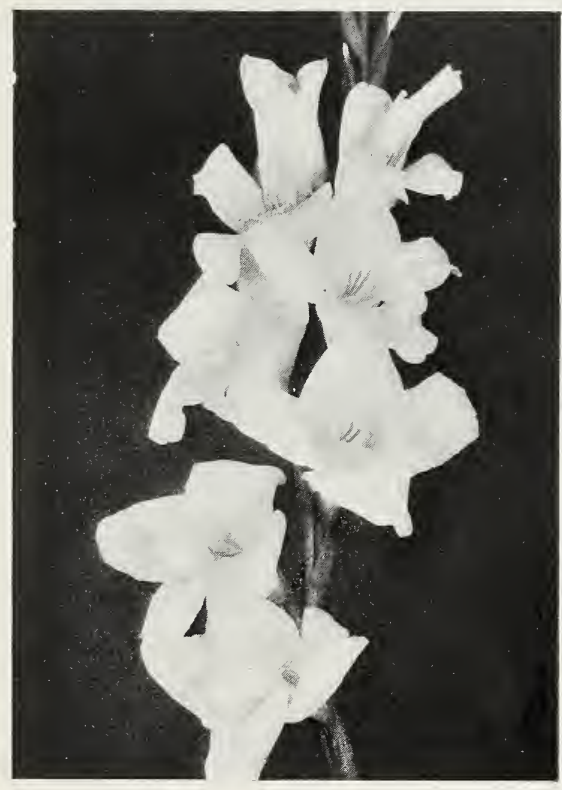

The White Gladioli are as chaste as lilies.
Chrysanthemums-Hardy. In red, pink, yellow, white and bronze. Separate or mixed colors. 25 cents each, $\$ 2.50$ the dozen.

Columbines-Mrs. Scott-Elliott strain, which has taken prizes all over Europe. Very long spurs and delicate colors - no off shades or clumsy double blooms. Big twoyear plants for immediate effect. 50 cents each, $\$ 5.00$ the dozen.

Columbines-Rose shades. Long spurred and ranging through the pink tones. Heavy two-year plants. 50 cents each, $\$ 5.00$ the dozen.

Coreopsis Lanceolata - Bright golden flowers, single and on long stems, each plant a mound of bloom. Extra large plants. 30 cents each, $\$ 3.00$ the dozen.

Cotoneaster Microphylla-One of the best of low-growing evergreen plants. Horizontal branches, bright red berries in winter. Strong plants with lots of root system. 50 cents each, $\$ 5.00$ the dozen.

Delphinium-Belladonna - The heavenly blue found in no other flower. Blooms all summer. Four feet. Strong plants. 40 cents each, $\$ 4.00$ the dozen.

Delphinium Sinesis-Intense blue, two feet tall. Blooms several times in summer. Strong plants. 40 cents each, $\$ 4.00$ the dozen.

Dianthus Deltoides-Tiny pinks in greatest profusion make this most charming in the border. 35 cents each, $\$ 3.50$ the dozen.

Doronicum-Single yellow flowers, three inches across, 15-inch stems. One of the earliest glints of sunshine in the garden. 25 cents each, $\$ 2.50$ the dozen.

Eryngium-Oliveranum-From a tuft of glossy leaves rises a branched flower stem some four feet tall, with thistle-like flowers of sage green which later assume an amethyst sheen. Distinctive. 40 cents each, $\$ 4.00$ the dozen.

Eryngium-Zabeli-A bolder type, forming fine specimen clumps in the garden. 50 cents each, $\$ 5.00$ the dozen.

NOTE-Both Eryngiums dry satisfactorily for winter bouquets. 


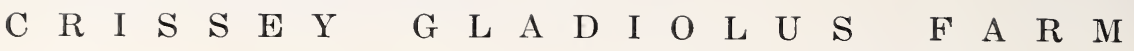

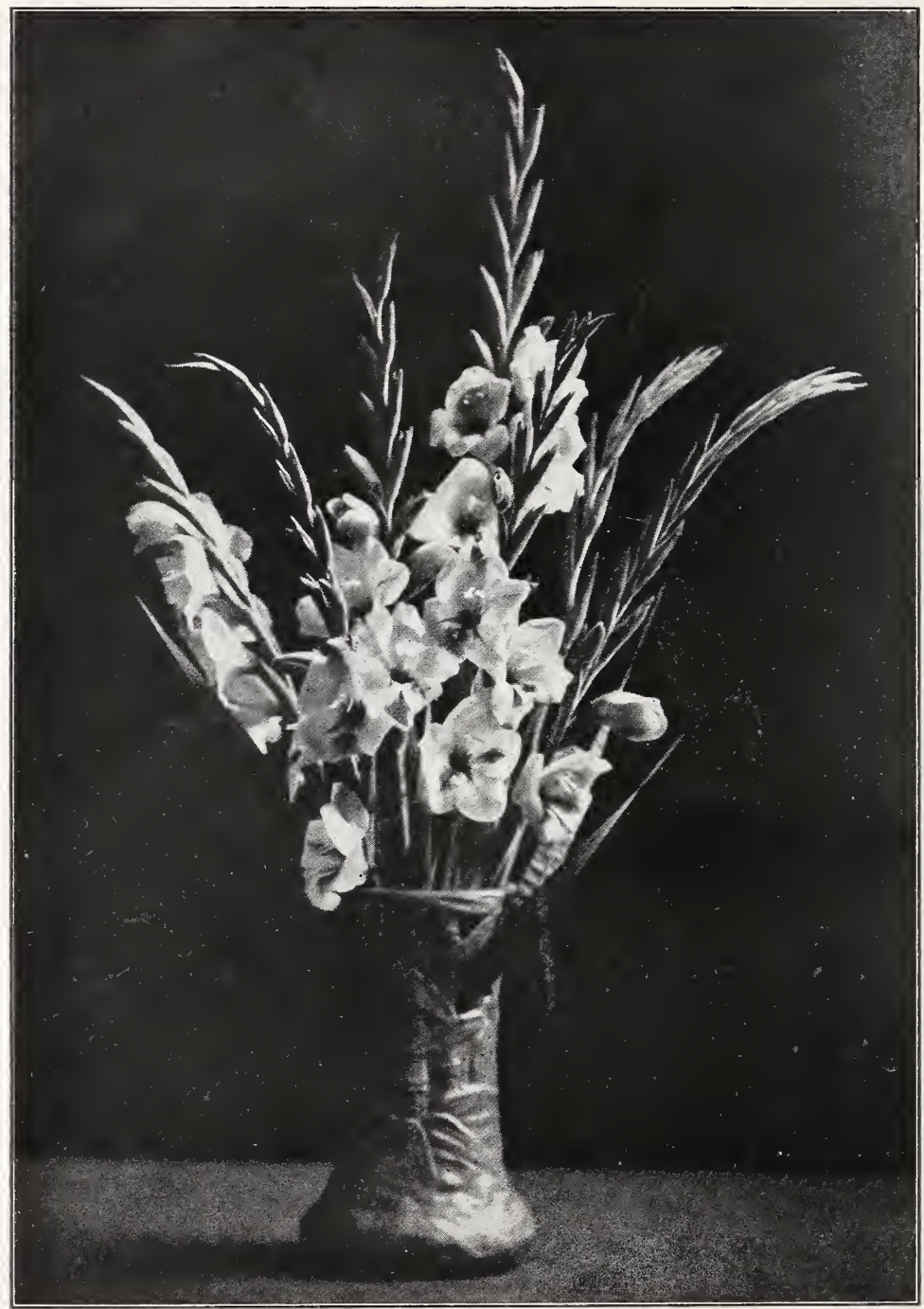

Gladioli retain their beauty for at least a week after cutting, and open all their buds in water. 
Gaillardia-Grandiflora-Deep yellow single flowers on 18-inch stems. Flowers often zoned with brown or red. A favorite for cutting. 25 cents each, $\$ 2.50$ the dozen.

Gaiffardia-"Crimson Glow"-An unusual and very rich shade. Large blooms. 40 cents each, $\$ 4.00$ the dozen.

Geum-Bright red flowers, handsome foliage. Blooms constantly from May until frost. Two feet. 25 cents each, $\$ 2.50$ the dozen.

Gypsophila-Acutifolia-Fine white flowers like a mist. Fragrant and earlier than Paniculata. 25 cents each, $\$ 2.50$ the dozen.

Gypsophila-Paniculata - Dainty white flowers in great masses. Lends grace to any bouquet. 25 cents each, $\$ 2.50$ the dozen.

Harpalium-Long golden petals around a brown center, like a refined and glorified sunflower. Six to eight feet tall and well adapted to the back of a perennial border, planting against a garage or lattice. 35 cents each, $\$ 3.50$ the dozen.

Heleniums-Magnificent for massing in the autumn garden. All varieties commence to bloom in late August in my garden.

Autumn Queen-Old gold, reverse of petals copper.

Riverton Beauty-Pure lemon yellow.

Riverton Gem-Rich copper bronze. All Heleniums, 35 cents each, $\$ 3.50$ the dozen.

Helianthus Soleil d'Or-Resembles Golden Glow, but is superior in every respect, growing upright without support and covered with bloom for several months in late summer. Beautiful for an informal hedge, or planted with tall perennial asters. 25 cents each, $\$ 2.50$ the dozen.
Helianthus Sparsifolius-Single flowers of bright yellow, brown central disc. Four feet. Midsummer. Spreads rapidly from the root, and should be planted where it will not encroach upon other flowers. Is fine to cut and for naturalizing in outof-the-way corners. 15 cents each, $\$ 1.50$ the dozen.

Hesperus Matronalis-White flowers, very sweet, usually in bloom by Decoration Day. Two feet. 25 cents each, $\$ 2.50$ the dozen.

Heuchera-"Coral Bells"-Tiny pink or crimson bells hung on graceful stems. 15 inches. Summer. 35 cents each, $\$ 3.50$ the dozen.

Hollyhock- "Newport Pink"-Very double, charming pink. Nothing more stately in the garden. 25 cents each, $\$ 2.50$ the dozen.

Iberis Gilbraltica-Perennial evergreen candytuft, with abundant rosy lavender flowers in early spring. No plant was more admired at the Farm this past season. 35 cents each, $\$ 3.50$ the dozen.

Iberis Sempervirens - "White Rock" Completely covered with white flowers in early spring. A fine companion to the preceding. Large plants, 35 cents each, $\$ 3.50$ dozen.

Japanese Anemone-"Queen Charlotte"Lavender pink semi-double flowers from August until frost. Three feet. Will thrive in half shade. Among choicest of all perennials. 35 cents each, $\$ 3.50$ the dozen; larger plants, 50 cents each, $\$ 5.00$ the dozen.

Lavender-What can be more delightful than a specimen bush or an informal hedge of lavender, with its silvery gray foliage and spikes of concentrated perfume? Fine plants, 40 cents each, $\$ 4.00$ the dozen; large specimens, $\$ 1.25$ each.

Lilac-Common purple, that old-fashioned shrub of delicious fragrance and pleasing memories. 50 cents each, $\$ 5.00$ the dozen.

\section{JAPANESE IRISES}

Embraced in the collection are purple, lavender, white and blue flowers, single and double. The flowers are broad and flat, larger than saucers, and come in June and July. They are offered in mixture, and cannot be sent in separate colors at this time. 30 cents each, $\$ 3.00$ the dozen. 


\section{DAHLIAS}

It is unnecessary to describe this favorite of the garden. I offer but a dozen sorts, which have stood out in rather an extensive planting as being of extraordinary excellence.

Bertha Story - New giant decorative, very free blooming, a deep rose pink. $\$ 1.00$ each.

F. W. Fellows-Long narrow orange petals, gracefully arranged, and strong stems, are features of this greatly admired cactus dahlia. 75 cents each.

King of Autumn-A handsome decorative dahlia, old gold the color keynote. 75 cents each.

Magnificent-Splendidly formed cactus type flower, in color between a warm apricot and amber. Most admired of all. $\$ 1.50$ each.

Mrs. Edna Spencer-Cactus flowered. Clear dainty lavender, without the usual pink tinge. Fine stems. $\$ 1.00$ each.

Pierrot-Deep amber shading to salmon center, petals distinctly tipped white. Cactus. 75 cents each.
Black Beauty-An immense peony-flowering dahlia of richest red black. Free flowering. $\$ 1.00$ each.

Rapiere-Gold tinted salmon, large and attractive. Hybrid cactus. 50 cents.

Rheinischer Froscheim-The predominating color is a warm cerise, with white intermingled. Cactus. Extra. 75 cents each.

Richard Box-Brilliant yellow cactus, like huge chrysanthemum. 50 cents.

Rose Nymph-For cut flowers this is unexcelled. Shell pink decorative; very lasting a nd floriferous. 35 cents each.

St. Elias-Pure white cactus, finest of this color. $\$ 1.00$ each.

\section{A DAHLIA COLLECTION TO BE PROUD OF}

One each of the twelve prize-winners listed above will be sent for $\$ 9.00$, charges prepaid. List value, $\$ 9.85$.

\section{START AN IRIS GARDEN}

I will send 12 choice irises for $\$ 5.00$, all charges prepaid, and promise a value considerably in excess of that amount. My selection will naturally take into account the fact that $I$ have large stocks of some fine sorts; in others a stock too small to catalog. I promise you will be pleased.

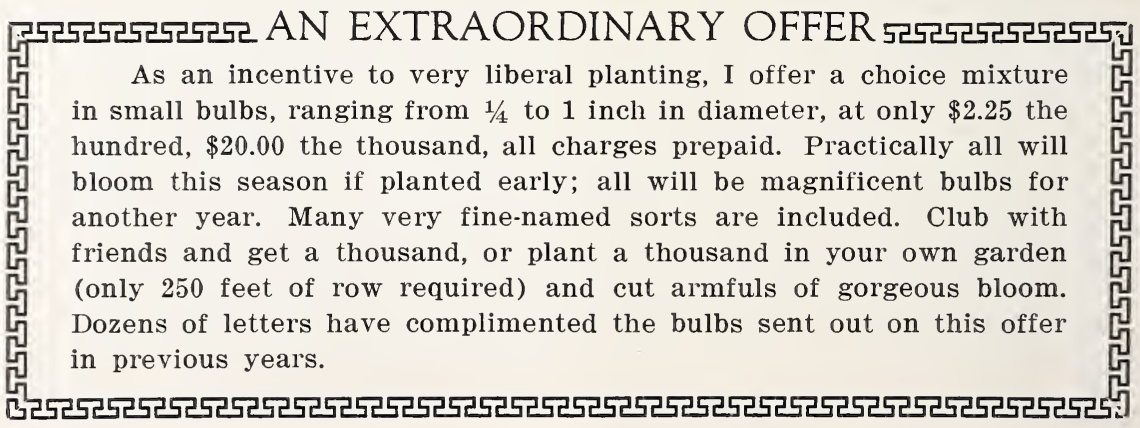

\section{PLANTS FOR THE ROCKERY}

Several plants described in the perennial list are well adapted to the rockery (though they thrive equally well in the garden), so I will mention them:

Iberis Sempervirens and Gilbraltica, phlox sublata, heuchera, saxifrage umbrosa and megesa, purple viola, dianthus deltoides, aster sub-coerulescens, saponaria ocymoides. 


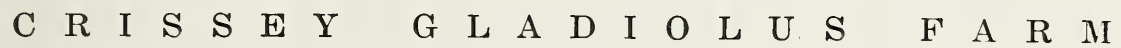

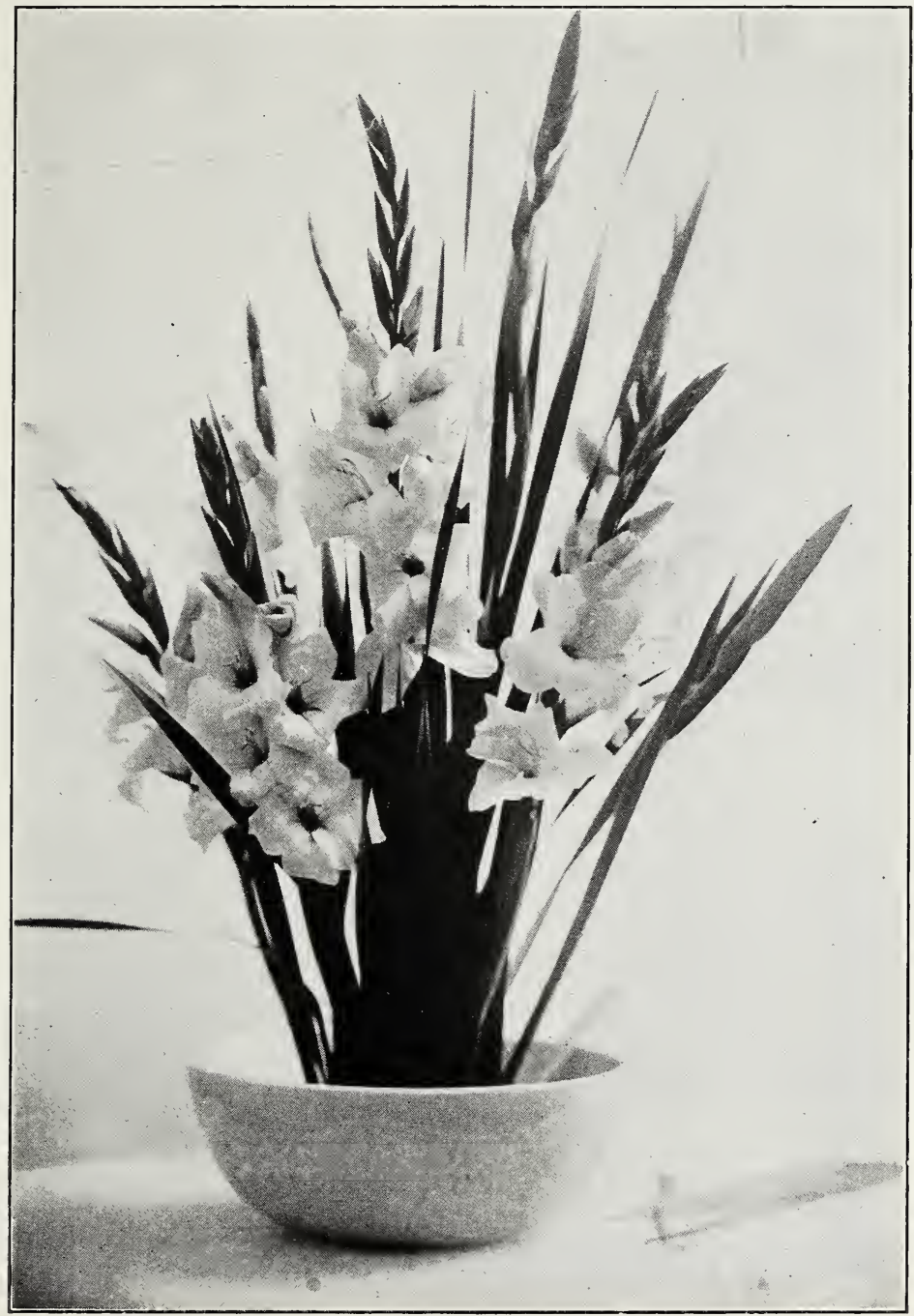

Arrangements like this are only possible by using heavy glass frogs to support the flowers. The frogs are equally good with irises. 


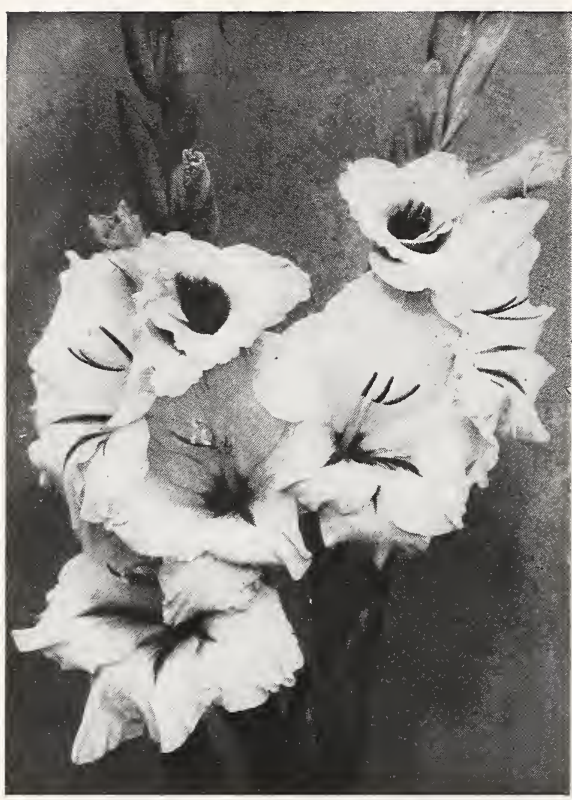

Ruffled petals enchance the beauty of this bloom.

Pyrethrum "Persian Daisy" - Single flowers of great beauty and lasting quality. 18 inches tall. June.

Mixed-Including white. Shades of pink and red. 40 cents each, $\$ 4.00$ the dozen.

Cerise Queen-Velvety cerise, especially rich under artificial light. Small clumps. 50 cents each, $\$ 5.00$ the dozen.

Rudbeckia Purpurea - Big rose-colored daisies with prominent brown cone in center. Unique and decorative. Two feet. 40 cents each, $\$ 4.00$ the dozen.

Saponaria Ocymoides-Trailing plant for rockery or border. A mat of flowers in May. 25 cents each, $\$ 2.50$ the dozen.

Saxifrage Megesa - Broad evergreen leaves, umbels of soft pink flowers on 18-inch stems in extremely early spring. 40 cents each, $\$ 4.00$ the dozen.
Saxifrage Umbrosa-Small tufts of fleshy green leaves, much branched red stems bearing tiny pink blossoms. 15 cents each, $\$ 1.50$ the dozen.

Shasta Daisy-Single white flowers, four inches in diameter, yellow centers. I offer two forms:

No. 1-Many branches, forming a mound of white bloom, striking in the garden. 25 cents each, $\$ 2.50$ the dozen.

No. 2-Single stems 18 inches long: for each flower; very superior for cutting. 25 cents each, $\$ 2.50$ the dozen.

Stokesia Cyanea-"Cornflower Aster"Like a very large blue cornflower, but perennial. 25 cents each, $\$ 2.50$ the dozen.

Sweet William-Holborn Glory-Individual flowers the size of quarters, trusses extra large. Deep red, zoned with white, giving general effect of a black and white combination. 25 cents each, $\$ 2.50$ the dozen.

Sweet William-"Scarlet Bedder"-Dazzling scarlet. 25 cents each, $\$ 2.50$ the dozen.

Tritoma-"Express Hybrids"-Luxuriant clumps of rush-like foliage of tropical appearance. Spikes of flowers in varying shades of orange and yellow, on five-foot stems. 35 cents each, $\$ 3.50$ dozen.

Tritoma-"Torchlight" - A rare dwarf form only 18 inches tall, very beautiful when cut and combined with deep blue delphiniums. 50 cents each, $\$ 5.00$ the dozen.

Viola-Deep purple, in form and color very close to the true violet. Plant soon forms a broad mat and blooms prodigally for six months of the year if the flowers are kept sheared. Absolutely unequalled for rich bedding effect, bordering walks or drives. Little known here. 25 cents each, $\$ 2.50$ dozen. 


\section{PEONIES}

"Regal" is the only word adequately describing these big balls of fragrance and beauty. My collection includes about sixty high-grade sorts, but the few I offer as a beginning are those of most modest price, though each has held its place for years through sheer merit and beauty.

Peonies should NEVER be transplanted in the spring, but in August and September, as they begin their growth long before spring, and bloom and vigor are always sacrificed by moving at this season. I send out one-year plants, not mere root divisions. All those offered are double-flowered.

INCLUDE WITH YOUR SPRING ORDER AND THEY WILL BE SENT AT PROPER PLANTING TIME.

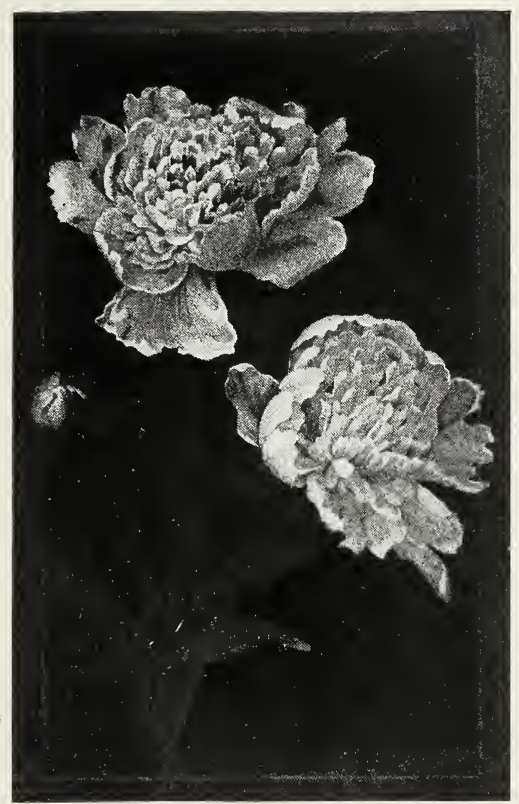

If only a picture could carry the peony's fragrance
Festiva Maxima-Large white flower, center showing splashes of crimson. Free blooming. Early. 75 cents each, $\$ 7.50$ the dozen.

Felix Crousse-Compact, globular bloom of bright red. Mid-season. $\$ 1.25$ each, $\$ 12.50$ the dozen.

Marguerite Gerard-Flesh pink, fading to white. Just a few stamens in the center. Late. $\$ 2.25$ each, $\$ 22.00$ the dozen.

Monsieur Jules Elie-Pale lilac rose, with lighter collar. Early and fine. $\$ 1.50$ each, $\$ 15.00$ the dozen.

Triomphe de I'Exposition de Lille-Light shell pink, splashed with violet rose. Mid-season. $\$ 1.00$ each, $\$ 10.00$ the dozen.

Peonies often fail to bloom on account of too deep planting. Two inches of earth over the topmost bud is plenty. Do not judge them by the first year's bloom, though the roots I send will usually give pleasing flowers even then. 


\section{SUMMER BEDDING PLANTS}

These are started under glass, are strong plants of varieties not ordinarily to be had here, and consequently worth more than the stock generally offered. They are grown from the choicest of English seed.

KELWAY'S ASTERS-The last word in these popular flowers. They resemble chrysanthemums:

Delight of the West-Rose pink. $\$ 1.00$ the dozen.

Grace of the West-Pale lavender. $\$ 1.00$ the dozen.

Cosmos Kelwayana-Newly created type in lovely pink. The center is like a cushion, surrounded by guard petals. $\$ 1.00$ the dozen.

\section{MARIGOLDS-}

Legion of Honor-Beautiful dwarf single for bedding. Yellow petals with crimson spot at base. Blooms from June until frost. 75 cents the dozen, $\$ 5.00$ the hundred.

Orange African-Tall, growing with rich orange flowers; fine cutting material. Very double. 75 cents the dozen, $\$ 5.00$ the hundred.

\section{MARIGOLDS-}

Kelway's Giant Tree-Flowers of the French type, the plant often attaining a height of more than six feet. $\$ 1.25$ the dozen.

SALPIGLOSSIS - Exquisite bell shaped flowers with conspicuous veining. Profuse.. bloomers. Two feet. Handsome mixed colors. $\$ 1.00$ the dozen.

SALVIA SPLENDENS - The dazzling scarlet sage. 75 cents the dozen.

SNAPDRAGONS-Can be left in gardens here as perennials. Three feet: Nelrose-Silvery pink. $\$ 1.50$ dozen.

Ghestia-Deepest crimson. $\$ 1.50$ dozen.

ZINNIAS-Kelway's Giant Flowered-In all the harmony of fall colors which make this flower so popular. 75 cents the dozen, $\$ 5.00$ the hundred.

Bronze Sunflower Seed-Easily grown annual. Single sunflowers exhibiting velvety bronze and crimson on a background of gold, like immense gaillardias. Most decorative. Liberal packets, 25 cents.

\section{A FEW CHARMING GARDEN COMBINATIONS}

Which have accidentally discovered themselves in my gardens, and which perhaps you would like to try:

Irises Liberty, Pallida Dalmatica and Juniata together.

Queen of May and Her Majesty irises with Iberis Gilbraltica, the lavender candytuft.

Princess Victoria Louise and Flavescens irises.

"Louise" gladioli with pink perennial physostegia.

Panthenon Phlox with Gypsophilia Paniculata.

Robert Parker or Praecox Asters with Helianthus soleil d'or.

Doronicum as a background for Belle Alliance or Kaizerkroon tulips; a study in scarlet and gold.

Helenium Riverton Gem, with Helenium Autumn Queen.

Royal Blue forget-me-nots with Alyssum saxatile or perennial white candytuft.

Tritoma "Torchlight" with Delphinium Sinesis.

Eryngium Oliveranum with Halley Gladioli. 


\section{ORDER BLANK}

W. L. CRISSEY

\section{Gladiolus Farm}

\section{Boring, Oregon}

Date.

Name

Street or Rural Address.

City.

State.

Remittance enclosed $\$$

If unable to send every item ordered, shall I substitute?

Quantity




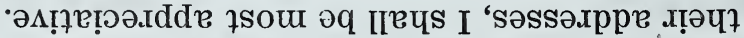

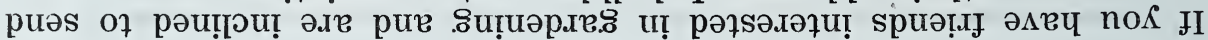

S్पㅂWヨy

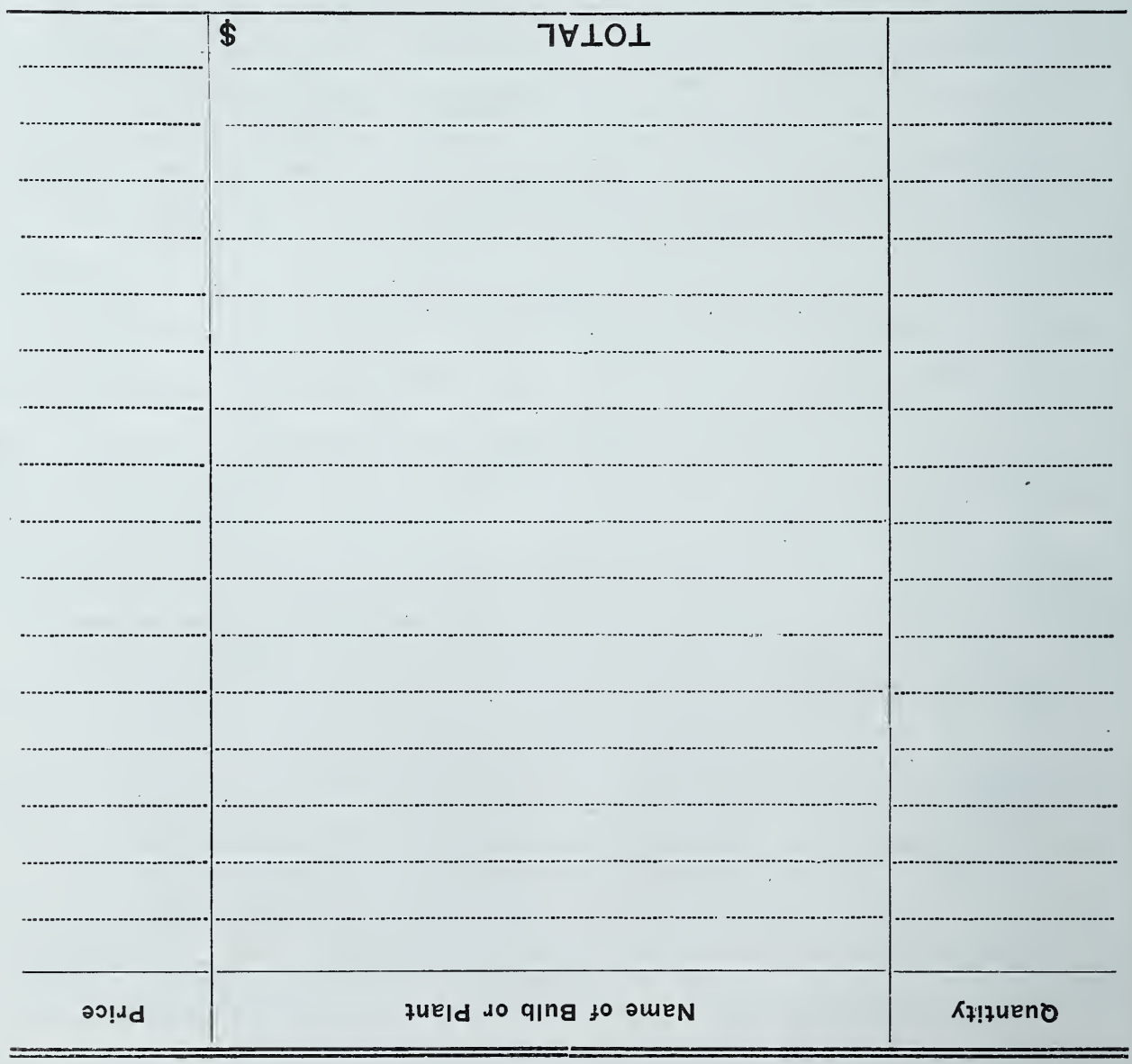




\section{"OLD FRIENDS" COLLECTION}

Four each of the following:

Butterfly-Brilliant salmon.

Panama-Deep pink.

Rouge Torch-Cream and crimson.
Principine-Scarlet and white.

Halley--Beautiful coral.

The 20 bulbs for $\$ 1.50$, postpaid.

\section{"DELIGHT OF THE GARDEN" COLLECTION \\ Six bulbs each of:}

IVar-Intense crimson.

Scliwaben-Soft yellow.

Peace--Stately white.

Anna Eberius-Velvety purple.
Willy Wigman-Cream with rose throat.

Herada-Glistening mauve.

The 36 bulbs for $\$ 5.00$, postpaid.

\section{"THE THOROUGHBREDS"}

One bulb each of these exquisite and high-class sorts:

Majestic-Orange pink.

Mrs. H. E. Bothin-Pink and crimson.

Louise-Finest lavender.

Mrs. Dr. Norton-White merging into pink.

Crimson Glow-Immense and purple.

Orange Glory-Massive ruffled orange shade.

Muriel-Softest blue.

Prince of India-Subtle dull tones.
Nora-Light blue.

Bengal Tiger-Old rose novelty.

Mrs. John R. Walsh-Loveliest pink of all.

Violet Glory-Deep violet, ruffled.

Jack London-A grand salmon.

Etendard-Cream, blotched crimson

Blue Jay-Fine blue. and yellow.

The 15 bulbs for $\$ 10.00$, postpaid.

\section{N D E X}

Page

Page

Charming Garden Combinations.. 22

Dahlias

Phlox

Gift Boxes

18

Primroses

Gladioli

Rock Plants

Irises

Special Collections--

Gladioli

Irises

23

Dahlias

18

Lilies

Peonies

Perennials

Summer Bedding Plants. 


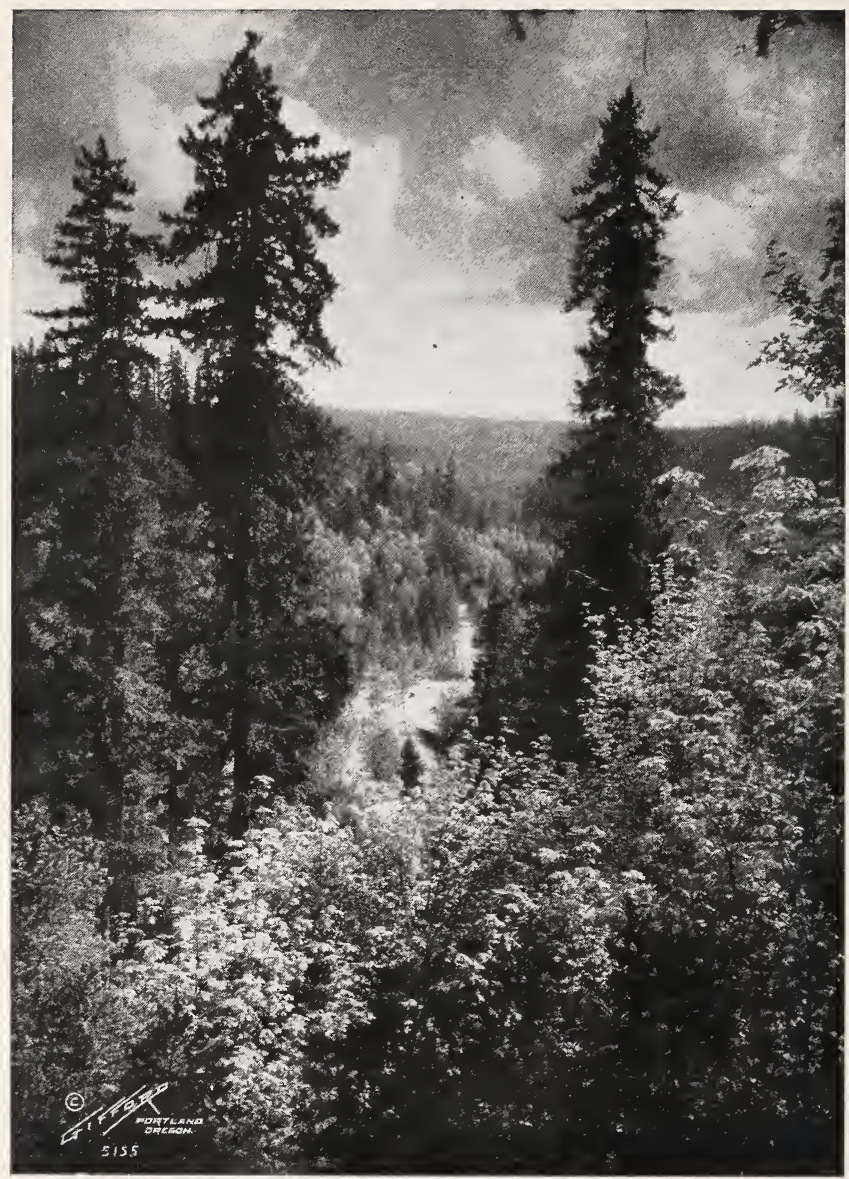

A charming vista from the farm

\section{W. L. CRISSEY \\ "GLADIOLUS FARM" \\ R. F. D. 1, Boring, Oregon}

